\title{
CrimRxiv
}

\section{Polycentric Security Governance and Sustainable Development in the Global South}

Julie Berg, Clifford Shearing

Published on: Jun 26, 2021

DOI: $10.21428 / \mathrm{cb} 6 \mathrm{ab} 371.675 \mathrm{dfce} 2$

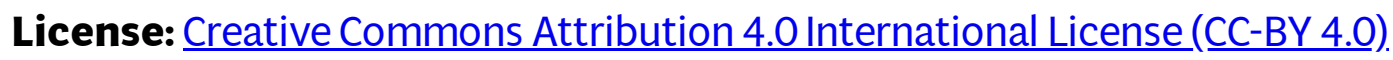


